\title{
Use of MOOCs in Health Care Training: A Descriptive-Exploratory Case Study in the Setting of the COVID-19 Pandemic
}

\author{
Francisco Gómez Gómez ${ }^{1}$ (D) and Pilar Munuera Gómez ${ }^{2, *(D)}$ \\ 1 Departamento de Servicios Sociales y Fundamentos Histórico-Jurídicos, Universidad Nacional de Educación \\ a Distancia (UNED), 28040 Madrid, Spain; fgomezg@der.uned.es \\ 2 Departamento de Trabajo Social y Servicios Sociales, Universidad Complutense de Madrid, \\ 28223 Madrid, Spain \\ * Correspondence: pmunuera@ucm.es
}

check for

updates

Citation: Gómez Gómez, F.;

Munuera Gómez, P. Use of MOOCs in

Health Care Training: A

Descriptive-Exploratory Case Study

in the Setting of the COVID-19

Pandemic. Sustainability 2021, 13,

10657. https://doi.org/10.3390/

su131910657

Academic Editor: Jose

Ángel Martínez-López

Received: 27 August 2021

Accepted: 22 September 2021

Published: 25 September 2021

Publisher's Note: MDPI stays neutral with regard to jurisdictional claims in published maps and institutional affiliations.

Copyright: (c) 2021 by the authors. Licensee MDPI, Basel, Switzerland. This article is an open access article distributed under the terms and conditions of the Creative Commons Attribution (CC BY) license (https:/ / creativecommons.org/licenses/by/ $4.0 /)$.

\begin{abstract}
This exploratory study is part of the training and innovation project (GID2016-16) of the National University of Distance Education (UNED) in Spain. The current socioeconomic and educational contexts derived from COVID-19 has led university institutions to develop methodological innovations in the teaching-learning process. Among these strengthening measures are the MOOCs, the most appropriate strategy to bring students closer to new digital platforms that favor the acquisition of knowledge. A methodological pluralism, combining quantitative and qualitative perspectives, has been used. The main results of the descriptive analysis compare the data of students enrolled in the MOOC, "Social and Health Care and Social Services in Social Work", and other related bachelor's and master's degree courses during the four years analyzed. One of the conclusions is the emerging possibility of offering university studies that are more in line with the current teleworking market. The development of online methodologies favors the democratization of education, reaching the student body as a whole and universalizing content and learning. Among the main conclusions, it is worth highlighting the degree of satisfaction shown by the students who took advantage of the MOOC, and the training opportunities afforded by MOOC courses, during the time of COVID-19.
\end{abstract}

Keywords: MOOC; COVID-19; social and health services

\section{Introduction}

The UNED is one of the most important distance learning universities in the world and it has the largest number of students of all the Spanish universities [1]. Half a century after its creation, the UNED has been consistently within the lines that marked its creation and its statutes, and it is by far the leading Spanish university in terms of the number of students [2]. In addition to third-cycle programs, master's degrees, and specialization courses, a total of 28 degrees are currently taught in its different faculties, technical schools, and associated support centers. These centers are located both throughout the country and abroad, as well as in prisons. Currently, the UNED employs more than six thousand people, consisting of teachers, tutors, and administrative staff.

The project was carried out during the academic years $2017 / 2018$ to $2020 / 21$. Teaching was affected because of the health crisis caused by COVID-19, which has affected all social spaces, including education, and meant an unexpected contingency in the planning of the educational project of both the UNED and all higher education institutions. During this period, Spain has experienced different crises due to the incidence of the virus, which has made it necessary to develop alternatives in the face of substantial and decisive changes, and to establish contingency plans that adapt to the current reality at any given time. In response to this pandemic, various measures have been taken through a wide-ranging legal framework. These include the Royal Decree 463/2020 of 14 March, which declared a state of alarm for the management of the health crisis caused by COVID-19 [3]. This Royal Decree set in motion the first measures aimed at protecting the health and safety of citizens 
in order to contain the progression of the disease and reinforce the public health system. Despite the urgent measures of prevention, containment, and coordination in the face of the health crisis caused by COVID-19, the population continues to suffer from different contagion crises, due to the number of variants of SARS-CoV-2 [4] and is experiencing burnout and emotional stress in social situations, which are considered essential.

According to statistics from the Ministry of Health [5], the infection rate of those aged 20 to 29 years was 1.421 cases per 100,000 inhabitants, as of 13 July 2021. These circumstances prompted us to realize the need for training them in social and healthcare contexts while, at the same time, taking into consideration their vaccination status and continuing to maintain the security and prevention measures in place given their high mobility. This pandemic calls for the consolidation of health and social care training through massive open online courses (MOOCs) because of their easy accessibility, with feasibility and relevance being two emerging variables in the current situation, which help to consolidate the advantages of this methodological possibility. Another advantage is the opportunity it offers students [6,7], especially those students who have difficulty accessing it $[8,9]$. There are proven educational advantages for students in the digital age. This conclusion is based on the contributions made by the leading representatives and researchers who have studied this type of teaching, or MOOCs, in-depth, including Gómez Galán [10,11].

The student in this type of course has the opportunity to learn without having problems with timetables or travel [12-17], which implies that using MOOC technology can improve teaching and learning in flexible environments given its potential $[18,19]$. This is particularly true during the months of greatest discomfort and the closure of university classrooms in order to prevent the spread of COVID-19.

A MOOC is characterized as a course that has a learning-oriented structure and it must involve tests or assessments that verify the skills and competencies acquired. It is massive because the number of potential enrollees is unlimited and it does not require attendance. It is also open because the materials are freely accessible on the Internet, which does not imply that they can be reused in other courses. The UNED MOOCs are designed with a double objective: on the one hand, to disseminate knowledge among society, reaching new audiences, and improving the reputation of the university as an innovative entity and source of high-quality knowledge and, on the other hand, to serve as a marketing tool for teachers to promote their teaching activity and publications, and to attract new students to other courses.

The MOOC, "Social and Health Care and Social Services in Social Work", participated in the Connectad@s Project, developed by the Spanish Universities Ministry and the CRUE (Conference of Spanish University Principals), offering online education resources during the global COVID-19 crisis [20].

The UNED Abierta has been given the Open Resilience Award by Open Education Global (OEGlobal) for its project I Learn at Home. The award recognizes exemplary leadership, both individual and collective, and open education practices implemented to address opportunities and challenges arising from COVID-19. Among the MOOCs presented by UNED Abierta was the MOOC, "Social and Health Care and Social Services in Social Work" [21,22].

In 2013, the NMC Horizon Report: 2013 Higher Education Edition identified the impact that MOOCs would have on university education at different levels. This report points out that MOOCs are an increasingly popular option for online learning because they are highly accessible and free of charge. Moreover, we should not forget MOOCs are creative by nature, fostering creativity and professional competence in students [23-25]. The number of students enrolled in the main platforms verifies the usefulness of lifelong learning [26].

In this sense, this descriptive and exploratory study was carried out in order to answer the following questions: ¿Has the type of training offered by the MOOC, 'Social and Social 
Services in Social Work', managed to maintain student enrollment during COVID-19 at the same rate as other degrees?; and What is the level of satisfaction of the enrolled students?

Six editions of the MOOC: "Social and Health Care and Social Services in Social Work" has shown us that there is a need to offer training for professionals and graduates who, in their practice, need spaces for updating and reflecting on their activities. It is framed as an offering from "UNED Abierta", which has an extensive collection of online courses for anyone anywhere in the world who would like to access them for free, and it echoes the audiovisual and printed production that is carried out in the departments of the UNED, as is the case of the Department of Social Services and Historical and Legal Foundations, where research on this MOOC was carried out during the pandemic.

This work reports the data of the students who took the course, especially during the COVID-19 pandemic. The results have been compared with other nearby or related official UNED degrees, as well as some of the students' opinions and their results. Through the course, the students were able to distance themselves from everyday life in order to self-observe the professional concerns and tasks and personal realities that occupy them and that are in line with the experiences of other authors [27-30]. This educational framework, together with the need to promote online teaching at the university in times of uncertainty because of the situation generated by the COVID-19 pandemic, has led us to favor autonomy in the online learning process and to promote the MOOC, "Socio-sanitary and Social Services in Social Work".

The UNED is among the top 400 universities in the world for its methodology (Academic Ranking of World Universities) and is in the top position of the Spanish ranking, U-ranking 2020 [31]. The UNED Strategic Plan 2019-2022 aims to be: open, international, digital, and sustainable, given that the future calls for the modernization of the university [31].

\section{The MOOC "Social and Health Care Services in Social Work" in "UNED ABIERTA"}

\subsection{UNED'S MOOCS}

The Founding Charter of the UNED, the Decree 3270/1972 of 18 August 1972, by which the National University of Distance Education was created [32], includes these general guidelines that henceforth guided the activities and programs of the UNED. In the aforementioned Charter of Foundation, it is explicitly stated:

- $\quad$ The nature of the UNED, as a public university of state scope, with direct dependence on the Government and the Cortes de la Nación.

- The fundamental characteristic of the UNED is the non-presential nature of its teachings; teachings that it imparts at a distance throughout the national territory, and in which the Government and the Cortes Generals assume the competencies that the General Education Act attributed respectively to the Governing Council of the Autonomous Communities and to the Legislative Assembly.

- The functions, set out in Article 3 of the UNED Statutes, focus on the commitment to facilitate access to university education for anyone who has difficulties in accessing it in its more traditional forms. In addition, it encourages the use of techniques and experiences that make it possible to overcome the obstacle of distance and for lifelong learning for both students and their teachers and researchers.

The training activities at UNED are organized around two institutions. First, a central coordinating body responsible for unifying criteria, planning work, and carrying out the administrative functions themselves. In the case of the UNED, these tasks are carried out by the central headquarters, located in Madrid (Spain).

At the same time, and precisely because of the remote nature of UNED teaching and tutoring, this practice translates into personalized attention for students asking specific questions, and always accords with the procedures contemplated by the statutes of this university in line with the most innovative proposals [33,34]. It is precisely for this purpose that the associated centers exist, which, as mentioned in the introduction, can be found all over Spain and abroad. 
MOOCs are an initiative of the UNED Abierta that has the aim of transferring the knowledge of the UNED to society. UNED Abierta is UNED's learning platform for making massive open online courses (MOOCs) available to the general public. The main objective of UNED open courses is to promote online lifelong learning as an educational model with enormous potential to respond to the training of the emerging professional profiles demanded by the new labor market. Through this online lifelong learning strategy, it is possible to train and accredit skills and competencies that are not currently recognized or certifiable but that are, nevertheless, of interest to agents demanding new professionals who need profiles adapted to the new digital economy, and that promote knowledge-based entrepreneurship, training, interaction, and the launch of new entrepreneurial initiatives within the possibilities offered by the digital world.

It is in the previous objective in which the MOOC studied has achieved the greatest relevance and success among the more than four thousand professionals who have taken it during its six promotions developed in the last four academic years. This will be the comparative limit used to analyze the data of similar or related degrees in order to obtain sufficient indications of the training and professional processes that are underway, and whose effectiveness will depend on the attention to the needs faced and addressed by professionals so that their actions are optimal and appropriate to what society and its members demand of them. The importance of the quality of the MOOCs is noteworthy, as pointed to in studies by authors such as del Arco, Flores, Ramos-Pla, and Silva [35,36].

\subsection{Description of the MOOC, "Social and Health Care Services in Social Work"}

The course is framed within the need to design and develop social and socio-health services to implement professional interventions from the field of social work into problems such as COVID-19. Its design has taken into account other designs [37-39]. It has been adapted to train students in a more social approach [40], one that is more global or holistic than those offered by other more well-known or developed approaches, such as those rooted in biology, psychology, education, etc. These approaches are not as effective as expected in social situations created by illnesses or crises that become chronic or structural and that increasingly affect the need to design the bio-psycho-social interventions required by citizens when they experience extreme situations due to the loss of loved ones [41].

The main objective is to offer an open content approach to the socio-health and social approaches from social work for the coordination of services in social situations that go beyond the approach of each of the different professional areas involved [42]. The aim is to launch a training proposal that could lead to other postgraduate or continuing distance-learning actions.

The detailed syllabus offered for the course, and the topics, contents, and course materials, which were approved by the UNED Academic Committee and ratified by its Governing Council on 14 February 2017, are shown in Table 1.

The teaching team of the Department of Social Services and Historical and Legal Foundations has extensive experience in specialization courses, university extension, summer and open courses, as well as in training actions in other universities, as is the case of the UCM (Complutense University of Madrid).

The course is offered to students and university graduates interested in socio-health training that implements their professional competencies in the field of COVID-19. In the first six editions, a total of 4677 students enrolled, of which $86.5 \%$ were female university students, $12.2 \%$ were male university students, and $1.3 \%$ were other university students. This reveals that those interested in the training contents of the MOOCs are predominantly female. The average age was 34 years old, and the most specific feature was that those who took the MOOC were aged 25 years and under, representing $15.1 \%$ of the total. Those aged from 26 to 40 years old represented $52.5 \%$, and those aged 41 years and over represented $32.4 \%$, which reflects the fact that this type of postgraduate training and continuous training throughout working and professional life represents a resource not yet fully explored or, at least, not fully addressed by our university, in accordance with the social demand and 
need, as we will show and develop in this study. Education in health during the school stage that takes into account students and families is important so that teachers can have training in health education that is within their reach, as well as that of the families of the students that are trained [43].

Table 1. Topics, contents, and materials of the MOOC, "Social and Health Services in Social Work".

\begin{tabular}{|c|c|c|c|c|c|}
\hline & Title & & Readings & Audio-Visual Material & Evaluation \\
\hline Theme 1 & - & $\begin{array}{l}\text { Public Health and } \\
\text { Social Work, with } \\
\text { special reference to } \\
\text { the COVID-19 } \\
\text { pandemic. }\end{array}$ & $\begin{array}{ll}\text { - } & \text { Social Work and its } \\
\text { relationship with Health: A } \\
\text { historical relationship. } \\
\text { - } \\
\text { Social Work and the Public } \\
\text { Health System. } \\
\text { - } \quad \begin{array}{l}\text { Social Work from the } \\
\text { paradigm of complexity }\end{array}\end{array}$ & $\begin{array}{l}\text { - Public health and } \\
\text { social work }\end{array}$ & \\
\hline Theme 2 & - & $\begin{array}{l}\text { Health Social Work, } \\
\text { in times of pandemic. }\end{array}$ & $\begin{array}{l}\text { - } \quad \text { Professional competencies in } \\
\text { Social Work. } \\
\text { - } \quad \text { Tasks and actions of social } \\
\text { workers. A comparative } \\
\text { study between Spain } \\
\text { and Ecuador. } \\
\text { The classroom of knowledge } \\
\text { of Arequipa as training of } \\
\text { adults for the creation of } \\
\text { micro-enterprises in Peru. }\end{array}$ & $\begin{array}{l}\text { Explanatory videos of } \\
\text { social work in health }\end{array}$ & $\begin{array}{ll}- & \text { Test of topics } \\
1 \text { and } 2\end{array}$ \\
\hline
\end{tabular}

\begin{tabular}{|c|c|c|c|c|c|c|}
\hline Theme 3 & - & $\begin{array}{l}\text { Areas of Social } \\
\text { Intervention in } \\
\text { Health. Education } \\
\text { and health promotion }\end{array}$ & - & $\begin{array}{l}\text { Programmes for family and } \\
\text { social coexistence from a } \\
\text { culture of peace. }\end{array}$ & $\begin{array}{ll}\text { - Intervention in } \\
\text { mental health. } \\
\text { - } \quad \text { Family violence }\end{array}$ & \\
\hline Theme 4 & - & $\begin{array}{l}\text { Social Services } \\
\text { in Addiction }\end{array}$ & - & $\begin{array}{l}\text { The good father: paternal } \\
\text { model and responsible } \\
\text { motherhood }\end{array}$ & $\begin{array}{ll}\text { - } & \text { Addictions and } \\
\text { services. } \\
\text { - } \quad \text { Outreach to family } \\
\text { members of people } \\
\text { with addictive } \\
\text { behaviorsc }\end{array}$ & $\begin{array}{ll}- & \text { Test of topics } \\
& 3 \text { and } 4\end{array}$ \\
\hline Theme 5 & - & $\begin{array}{l}\text { Models for } \\
\text { professional } \\
\text { intervention }\end{array}$ & - & $\begin{array}{l}\text { Brief theoretical framework } \\
\text { for understanding practical } \\
\text { interventions. } \\
\text { Clinical social work. } \\
\text { Family, school and } \\
\text { mindfulness: how childhood } \\
\text { anger affects adult family } \\
\text { and couple life. }\end{array}$ & $\begin{array}{l}\text { Itinerary of the } \\
\text { social worker's } \\
\text { intervention. } \\
\text { - Models of } \\
\text { intervention }\end{array}$ & $\begin{array}{l}\text { Final test (Peer } \\
\text { assessment): } \\
\text { Personal critical } \\
\text { reflection on } \\
\text { the contents }\end{array}$ \\
\hline
\end{tabular}

Source: Prepared by the authors based on data from the UNED Information Processing Office.

With regard to the percentages of the studies undertaken by those enrolled, it should be pointed out that $66.6 \%$ were university graduates, $20.7 \%$ were university graduates, and $6.5 \%$ had secondary education. This emphasizes what was mentioned in the previous paragraph concerning the need for continuous training, if possible, that is tailored to the professional groups in demand rather than universalized training, which is already the object of the basic training for official qualifications. The fact that $6.5 \%$ of those registered have secondary education does not contradict the above, since vocational training studies 
exist as support and services for university graduates. According to the answer of the following student (E.12, from the second promotion (P. 2)):

The choice of this course was based on the fact that I am currently studying a VET in Social Integration. When I saw the title and the description of the course, I thought that it could provide me with enriching knowledge. And I was right.

(Vocational training student, second promotion (P. 2); student number (E. 12)).

Most of those enrolled had social work studies along with other related university degrees, such as psychology, pedagogy, social education, nursing, sociology, anthropology, etc. The internationalization of the course is shown by the participation of students of 41 different nationalities. In addition to Spaniards, participants came from European countries, such as France, England, Poland, Romania, Italy, Russia, Portugal, and Ukraine, as well as others, such as the United States, Ecuador, Mexico, Brazil, Peru, Argentina, New Zealand, Australia, Iran, etc.

The data in Table 2, on the geographical origin of the students, show an increasing trend towards internationalization according to the percentages presented of the students who took the six MOOC promotions during the five years analyzed in this study, comprising four academic years and six promotions carried out.

Table 2. Geographical origin of students. Source: Prepared by the authors based on data from the Statistical Portal of the UNED Information Processing Office.

\begin{tabular}{lllll}
\hline Year & \% Spain & \% Rest of Europe & \% Americas & \% Others \\
\hline 2017 & 71 & 14 & 11 & 4 \\
\hline 2018 & 65 & 15 & 13 & 7 \\
\hline 2019 & 60 & 16 & 14 & 10 \\
\hline 2020 & 48 & 24 & 16 & 12 \\
\hline 2021 & 42 & 19 & 18 & 21 \\
\hline
\end{tabular}

This training begins with higher percentages in the first years, with $71 \%$ of students coming from Spain, as this specialty does not exist in university institutions for students in the area of social work and the social sciences in general. During the years of the pandemic, the percentage of students of other nationalities increased as the high-quality, free, and accessible nature of the program became more widely known.

\section{Methodology}

A descriptive and exploratory study has been carried out in the context of COVID-19. The methodology followed in this research is based on methodological pluralism. From a quantitative approach, and using the secondary analysis technique of the student sample [43], an approximation has been made based on the data offered by the Statistical Portal of the UNED Information Processing Office. In addition, a qualitative methodology was used to analyze the opinions of the professionals and students who took the MOOC in its last compulsory exercise, consisting of a final peer review test. The students themselves, utilizing a questionnaire where they made an anonymous critical reflection on the contents of the course, carried out this participation. The questionnaire was taken online at the end of each of the five courses carried out. This research was carried out following the ethical principles of research set out in the Declaration of Helsinki.

For the secondary analysis of the data on the official bachelor's and master's degrees, the UNED Abierta Insights tool was used, which is provided by the MOOC's own computer application. Based on the aforementioned data, we compared the enrollments in bachelor's degrees in Social Work, Social Education, Criminology, and Legal Sciences and Public Administration in the last four academic years from 2017-18 to 2020-21. This study looks at those in which the six promotions of the MOOCs were taught, with the aim of finding 
and establishing approximations and similarities of training demands more in line with the needs of the different university professionals related, or close, to the contents offered by the MOOCs during times of pandemic.

At the same time, comparisons were made with those enrolled in the official master's degrees in General Health Psychology, Social Policies and Dependency, Human Rights, Professional Guidance and Innovation, and Research in Education, with the aim of gaining a better approximation to postgraduate studies that, despite often not being in line with the needs of continuous training throughout professional life, are closer to what is intended through the design and delivery of the MOOCs carried out.

Methodologically, triangulation has been used based on a literature review and the quantitative and qualitative analyses mentioned above. The bibliographic review in scientific databases, such as ProQuest Central, Education Database, Health \& Medical Collection, and DIALNET, provided 160 related publications, with the keywords "MOOC" and "COVID-19", and we have taken into account the procedures of evaluation experiences developed by other authors in other MOOC courses in our decision-making [44-51]. The sample consisted of 4677 students with the characteristics described above, participating in the quantitative and qualitative study, with a $52 \%$ share. The contents of the course are shown in Table 1.

A descriptive frequency study was carried out. In the procedure, the data of the five classes of pupils, and their opinions over the last four years, were studied. The objectives of this study were: firstly, (PO1), to find out whether there is the possibility of offering official qualifications, such as MOOC courses, to bachelor's and master's university graduates that are more in line with the labor market and its needs; secondly, (PO2), to study student satisfaction with the use of new teaching methodologies via the Internet; and finally, (PO3), to see if these methodologies can complement the existing distance learning methodologies, as is the case of the MOOC "Social and Health Services in Social Work" of the UNED.

\section{Results and Analysis}

The research results are divided into two subsections that cannot be conceived in isolation, the sum of both of which provides a general understanding of the phenomenon studied. Because of the characterization of the degrees within the European Higher Education Area, the data are presented differentiated into bachelor's and master's degrees.

\subsection{Comparison between MOOCs and University Degrees}

Participation in this MOOC has shown different behaviors for the bachelor's and master's degrees during the years analyzed. It was decided to use this differentiation to highlight the interests of the student body, especially during the year 2019-2020, affected as it was by COVID-19. For this reason, we first analyzed the enrollment data for the bachelor's degree, and then those for the master's degree.

Table 3 and Figure 1, show the enrollment data for the bachelor's degrees in Social Work, Social Education, Criminology, and Legal Sciences and Public Administration, with those enrolled in the MOOC during its six promotions taught in the last four academic years, from 2017-18 to 2020-21. Therefore, the data compared are also from these academic years because, although they may seem different and distinct in their purposes and duration, they show trends that may be useful and relevant in a first explanatory approximation of what has recently happened with the university situation created by the COVID-19 pandemic. 
Table 3. Comparison between students enrolled in the MOOC and related degrees (Total data and \% with respect to 20172018). Source: Prepared by the authors based on data from the Statistical Portal of the UNED Information Processing Office.

\begin{tabular}{|c|c|c|c|c|c|}
\hline $\begin{array}{l}\text { Academic } \\
\text { Year }\end{array}$ & $\begin{array}{c}\text { MOOC Socio-Health and } \\
\text { Social Services in Social Work }\end{array}$ & Social Work & $\begin{array}{c}\text { Social } \\
\text { Education }\end{array}$ & Criminology & $\begin{array}{c}\text { Legal and Public } \\
\text { Administration Sciences } \\
\text { Public Affairs }\end{array}$ \\
\hline 2017-2018 & 875 & 5391 & 5216 & 4006 & 2321 \\
\hline 2018-2019 & $\begin{array}{c}1213 \\
(38.6 \%)\end{array}$ & $\begin{array}{c}5195 \\
(-3.6 \%)\end{array}$ & $\begin{array}{c}5150 \\
(-5.9 \%)\end{array}$ & $\begin{array}{c}4850 \\
(21.7 \%)\end{array}$ & $\begin{array}{l}2385 \\
(2.7 \%)\end{array}$ \\
\hline 2019-2020 & $\begin{array}{c}1685 \\
(92.5 \%) \\
\end{array}$ & $\begin{array}{c}5037 \\
(-6.5 \%) \\
\end{array}$ & $\begin{array}{c}4901 \\
(-10.5 \%) \\
\end{array}$ & $\begin{array}{c}5311 \\
(32.7 \%) \\
\end{array}$ & $\begin{array}{c}2552 \\
(9.9 \%)\end{array}$ \\
\hline 2020-2021 & $\begin{array}{c}904 \\
(3.3 \%)\end{array}$ & $\begin{array}{c}5645 \\
(4.7 \%)\end{array}$ & $\begin{array}{l}5476 \\
(4.9)\end{array}$ & $\begin{array}{c}6344 \\
(58.4 \%)\end{array}$ & $\begin{array}{c}2808 \\
(20.9 \%)\end{array}$ \\
\hline
\end{tabular}

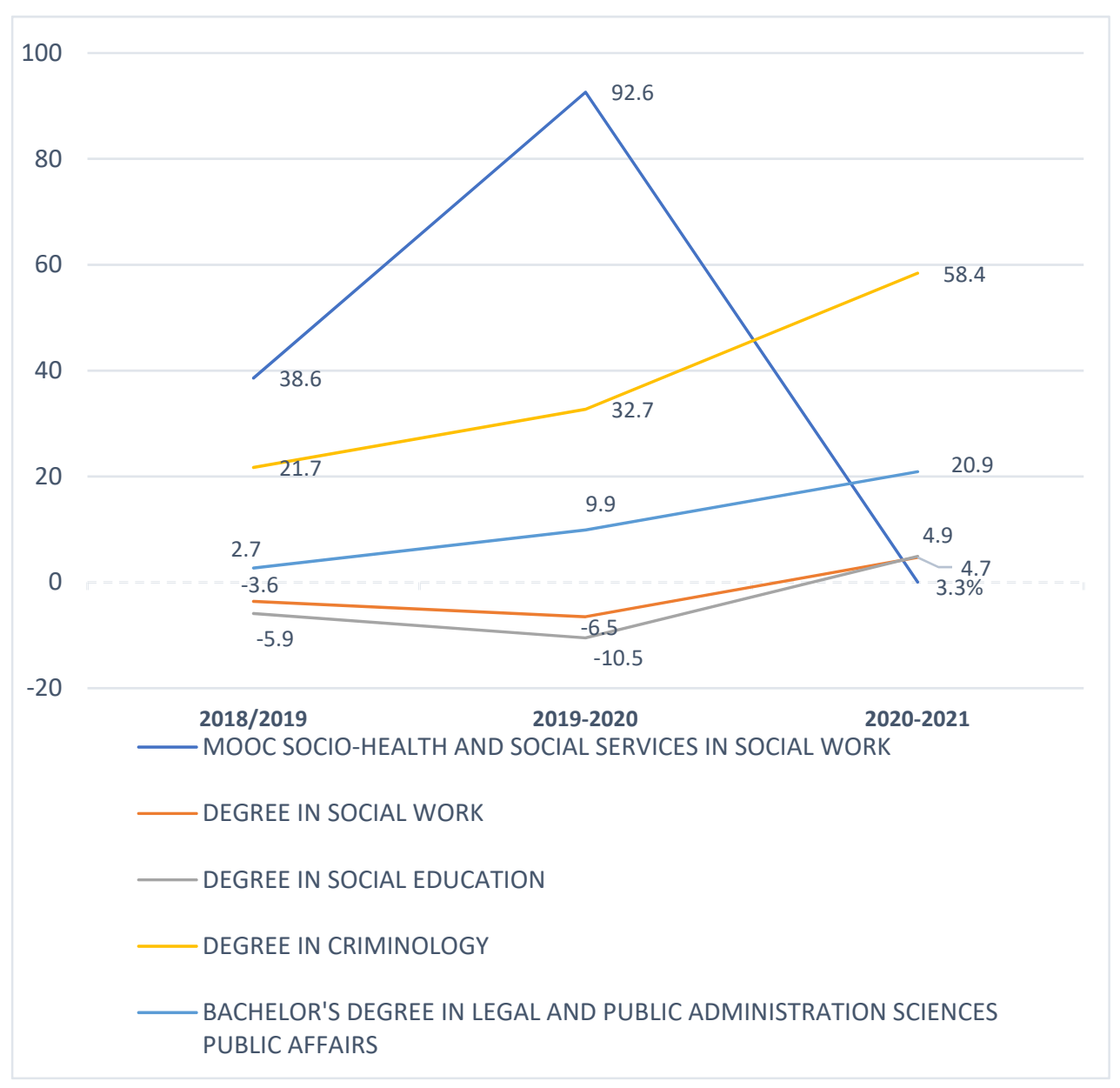

Figure 1. Percentage evolution between students enrolled in the MOOC and related degrees compared to the reference year 2018/2019. Source: Prepared by the authors based on data from the Statistical Portal of the UNED Information Processing Office.

In order to compare the enrolment data with the MOOC in those academic years, we have taken as $100 \%$ the number of students enrolled in the first academic year studied, 2017-2018, to observe the fluctuations in the number of students enrolled in the rest of the academic years. With regards to the MOOC data, we can see a significant increase in enrolment in the 2019-2020 academic year, with 1685 students and a percentage increase of $92.5 \%$ in relation to the initial course (2017-2018) with 875 students (100\%). In other words, the increase in MOOC enrollment occurred during the 2019-2020 academic year affected by 
COVID-19. These increased figures are not observed in the other degree courses analyzed during the COVID-19 pandemic. The rest of the degree courses maintain the same rate and percentage of increase, except for the criminology degree, which grows in 2020-2021, a situation that is not directly related to COVID-19.

The impact of COVID-19 can be seen directly in the increase of enrollments in the MOOC during the 2019-2020 academic years. The most drastic measures, such as closing classrooms and centers, were applied in this academic year, while enrollments in bachelor's and master's degrees were maintained or slightly reduced.

The increase in enrollment can be seen during times of pandemic. In four academic years, enrollment in the MOOC increased from 875 in the first year to 1685 in the third year, with a total of 4677 enrollments, for a course lasting six weeks, with a planned dedication of twenty-five hours (1 ECTS). The interest shown by the students and professionals who took the course was significant, and their opinions were very positive and indicative of the desire for a deepening of the training offered and its practices [52,53]. These opinions were elaborated by the students themselves and after a process of hierarchization by categories and subcategories, which we have included in order to show some of the opinions of the students who took the MOOC that reinforce the previous results and that are randomly reflected below.

The course and its contents take us, through its five themes, a little further than a simple explanation and enumeration of these services. In general, first of all, I would like to thank you for all the information and training I have received, as it is very helpful and enriching. This course helps to contribute to broaden my knowledge in this field and to develop skills to perform the functions within the health framework.

(Health professional student (P. 3; E.16)).

The MOOC offered enrollment figures that were close to the enrollment data of related university degrees and, in some cases, such as with the Degree in Legal Sciences and Public Administration, almost doubled them. The upward trends in enrollments in the degrees over the last two years coincide with the time of the COVID-19 pandemic, which is in line with what professionals have expressed about their training needs.

These new needs that appear in relation to women and which pose new challenges to the existing social services system also pose new forms of intervention and commitment on the part of social workers...Social transformation is constant and it is necessary to reinvent oneself and cover possible shortcomings...

(Student social worker (P.1; E. 21))

\subsection{Comparison between the MOOC and University Master's Degrees}

Table 4 shows the enrollment data for the MOOC, which greatly exceeds the data for the five master's degrees considered for comparison. It should be noted that other master's degrees that would have been appropriate for this comparison, because they are even closer or more similar than those studied, could not be considered because no data on them appear in the UNED Statistical Portal for the academic years studied, as is the case of the Master's Degree in Psychological Intervention in Development and Education and the Master's Degree in the Psychology of Social Intervention.

The figures for the 2019-2020 academic year, when the COVID-19 pandemic had the greatest impact, show the influence of COVID-19 on the increase of students in the MOOC. Furthermore, COVID-19 seemed to have no influence on the master's courses, as the number increased in one master's course and decreased in others. 
Table 4. Comparison between students enrolled in the MOOC and related master's degrees (Total data and \% with respect to 2017-2018). Source: Prepared by the authors based on data from the Statistical Portal of the UNED Information Processing Office.

\begin{tabular}{|c|c|c|c|c|c|c|}
\hline $\begin{array}{c}\text { The } \\
\text { Academic } \\
\text { Year }\end{array}$ & $\begin{array}{c}\text { MOOC } \\
\text { Socio-Health and } \\
\text { Social Services in } \\
\text { Social Work }\end{array}$ & $\begin{array}{c}\text { Master's Degree } \\
\text { in General } \\
\text { Health } \\
\text { Psychology }\end{array}$ & $\begin{array}{l}\text { Master's Degree } \\
\text { in Social Policies } \\
\text { and Dependency }\end{array}$ & $\begin{array}{c}\text { Master's } \\
\text { Degree in } \\
\text { Human Rights }\end{array}$ & $\begin{array}{l}\text { Master's } \\
\text { Degree in } \\
\text { Vocational } \\
\text { Guidance }\end{array}$ & $\begin{array}{c}\text { Master's } \\
\text { Degree in } \\
\text { Innovation } \\
\text { and Research } \\
\text { in Education }\end{array}$ \\
\hline 2017-2018 & 875 & 225 & 22 & 112 & 111 & 218 \\
\hline 2018-2019 & $\begin{array}{c}1213 \\
(38.63 \%)\end{array}$ & $\begin{array}{c}273 \\
(21.33 \%)\end{array}$ & $\begin{array}{c}44 \\
(200 \%)\end{array}$ & $\begin{array}{c}135 \\
(20.53 \%)\end{array}$ & $\begin{array}{c}91 \\
(1.98 \%)\end{array}$ & $\begin{array}{c}200 \\
(-1.74 \%)\end{array}$ \\
\hline 2019-2020 & $\begin{array}{c}1685 \\
(92.5 \%)\end{array}$ & $\begin{array}{c}277 \\
(123.11 \%)\end{array}$ & $\begin{array}{c}65 \\
(295.45 \%)\end{array}$ & $\begin{array}{c}116 \\
(-3.57 \%)\end{array}$ & $\begin{array}{c}94 \\
(-4.68 \%)\end{array}$ & $\begin{array}{c}241 \\
(10.55 \%)\end{array}$ \\
\hline 2020-2021 & $\begin{array}{c}904 \\
(3.31 \%)\end{array}$ & $\begin{array}{c}288 \\
(128 \%)\end{array}$ & $\begin{array}{c}81 \\
(368.18 \%)\end{array}$ & $\begin{array}{c}135 \\
(20.53 \%)\end{array}$ & $\begin{array}{c}86 \\
(-7.47 \%)\end{array}$ & $\begin{array}{c}204 \\
(-3.57 \%)\end{array}$ \\
\hline
\end{tabular}

The parity of data between the Master's in General Health Psychology, which is a master's with its own legal regulation for the practice of health psychology in our country (which explains the interest), and the Master's in Innovation and Research in Education (whose data may be due to the needs of different education professionals at different educational levels) to access accreditation in research and doctoral programs, given the large number of university graduates in our country, is striking. Regarding the data from the master's courses, the low rate of enrollment figures in comparison with the MOOC is notable. It is also appreciated that the enrollment in the Master's in Social Policy and Dependency exceeds the increase figures for the four years analyzed, reaching a $368.1 \%$ increase during the 2020-2021 academic year. Perhaps the initial training received in the MOOC motivated students to continue in the same department, given the high valuation and acceptance that students showed in their responses. The data for the Master's in Human Rights shows intermediate enrollment figures and are closer to those of the Masters in Career Guidance which, in principle, should be closer to the objectives of the MOOC studied. In the rest of the master's degrees studied, no significant fluctuations in enrolment were observed in relation to COVID-19, or to the impact of the training received in the MOOC.

From this point on, our descriptive analysis is completed with the opinions given by the students who have participated in the MOOC analyzed. The use of the qualitative perspective deals with the absolute data obtained from the survey and, therefore, the most clarifying "verbatims" obtained that support the quantitative data are incorporated in the results. The enrollment figures for the MOOC mostly exceed the enrollments of all the master's degree programs, which may again be an indication of the need for training that is more in line with professional development [54], and its practical application, which is more in line with what is most required.

\section{It has been revealing to stop seeing Social Work from the point of view of the resources that we can contribute to situations of physical illness, and see it from a concept of a profession that contributes to the concept of physical, emotional, relational, and psychosocial health, leaving aside the sectioned individual and treating him/her as what he/she is a complete and transversal being.}

(Health social worker (P. 4; E.3))

It is clear that the interest created in the professionals who took the MOOC is related to opening up training to other studies with the aim of improving social welfare. All of this has favored official master's degrees that are more in line with the current labor market than traditional training that has been mismatched, or that obeys training whose competencies are more typical of the bachelor's degree level of basic training. 
By way of conclusion and as an assessment, I have to say that the course gave me unknown points of view, the discovery of studies that show that the social sphere is becoming increasingly important in different aspects of our lives due to the importance that people themselves give to it...

(Social worker (P. 8; E. 10)

This contribution shows us the possibility and the opportunity of offering other degrees for professionals interested in social and health [55] care training, as well as their opinions and realities. In short, to advance what the world Health Organization (WHO) indicates: "health is a state of complete physical, mental and social well-being and not merely the absence of disease and handicap". Therefore, one of our objectives was to verify that university graduates need accessible and short-term training proposals that delve into the fundamental and changing aspects of the socio-health field and that adopt a holistic and bio-psycho-social view of the person.

I start from the humanistic basis of the being, understood as part of a system with personal and family history, based on respect and peace as healthy forms of coexistence, in which I understand that the individual is a bio-psycho-social being, who has his own resources and is the creator of his own reality...

(Social worker (P. 6; E. 4)

The figures show extraordinary interest in the MOOC training course, as reflected in Table 4, which shows an analysis of the number of students enrolled in the different courses, where the difference in the number of students enrolled can be seen. The results show that the MOOC results are much higher than those of the master's degree courses. It should not be forgotten that the comparison of the data between those enrolled in the MOOC in the last four academic years, and those enrolled in the master's degrees considered may not only be relevant because they are graduates [28] and university professionals, but also because resulting trends can be introduced in the improvement of the UNED distance learning and university offerings.

It opens the way to what, in other professional fields in countries such as the USA, Sweden, Norway, Finland, Denmark, as well as in others, such as Australia, is considered training for intervention by clinical professionals, usually a social health worker, psychologist, psychiatrist, or another professional with recognized postgraduate training [56]). Socio-health is a term that encompasses a wide variety of theories, methods, and techniques, and that has deep and lasting roots in medicine, traditional healing, psychology, social work, nursing, and education.

I cannot finish without mentioning the field of clinical social work, which is considered a specialty within social work and although it is not widely recognized today, as that would mean considering the social worker as a therapist who knows how to diagnose problems, it is on the rise and attracting more and more scholars.

(Health social worker (P. 6; E. 10)

In relation to the objectives set out, firstly, with regard to the first objective (PO1), it can be stated that there is the possibility of offering other official qualifications, such as MOOCs, to bachelor's and master's university graduates in order to implement their training and professional skills in accordance with the needs of the labor market. The MOOCs complement and initiate students in the professional competencies that enable them in their professional practice.

Secondly, the second objective (PO2) has been achieved, since the students' satisfaction with the use of the new teaching methodologies through the Internet has fulfilled their expectations, especially in the case of the MOOC, "Social and Health Services in Social Work" of the UNED of Spain. And finally, in relation to the third objective (PO3), the students themselves confirm that they are more in line with the current teleworking labor market and are closer to their current training needs, especially in the situation of the COVID-19 pandemic. 


\section{Discussion}

The reality was that, during the 2019/2020 academic year, the university abolished face-to-face teaching, which led to an increase in the number of students enrolled in our MOOC (1685). Subsequently, in the academic year 2020/21, universities returned to teaching in classrooms with security measures and, therefore, the number of students enrolled in our MOOC decreased (904). The increase in enrollment in bachelor's and master's degree studies may have been affected by the number of students who were unable to take these studies because of COVID-19 during the 2019/2020 academic year.

In this study, one of the most outstanding pieces of data is the evolution of the MOOC in recent years, especially as a result of COVID-19, given that there has been an exponential increase $(92.5 \%)$ compared to the reference year (2017/2018), and an increase of $38.9 \%$. However, as the social and health conditions improved, students returned to attend university after the harshest waves of the pandemic, during the academic year 2020/2021. As a consequence, there was a $53.6 \%$ drop in enrollment compared to the previous year, and only a 3.3\% increase is considered if we take the academic year 2017/2018 as a reference.

The characteristics of MOOCs allow for the possibility of offering university studies that are more in line with the current teleworking labor market. At the same time, the development of online teaching methodologies is implemented through this training modality. These courses allow education to be democratized to a greater number of students, reaching the student body as a whole, and universalizing content and learning that favors the development of their professional competencies [44], i.e., the new teaching methodologies via the Internet can complement the existing distance learning ones, as is the case of the UNED. In other words, massive open online courses, in addition to being free of charge, are a form of introductory training leading to more in-depth training. The COVID-19 pandemic has enabled graduate students and professionals to have access to consistent content, and the learning they have achieved is useful for their professional work. It also helps them to be more reflective and self-critical about their actions.

The UNED, due to its characteristics, can implement and explore this training modality, given its solid trajectory in online teaching, and open up a new source of training programs that complement the existing ones and its experiences.

E-learning training in a pandemic situation has offered the possibility of updating and implementing the training received by professionals in the social and healthcare areas thanks to the use of information and communication technologies (ICT). This type of training is very useful for university graduates [57], who carry out professional activities and have family responsibilities, as it allows them to achieve work/life balance $[28,58]$. The European Union stresses the need to coordinate health and social services to achieve a high level of quality and the effective use of resources and long-term care in their environments [55,59].

This training has the potential to prevent, or reduce, among other things, the possible addiction of young people to video games [60]. At the same time, it allows access to free training, facilitating the right of young people to access education and increasing their employability, especially in the situation created by COVID-19. It allows access to specialized training and complies with all safety and prevention measures. In other words, the offer of this type of training for young unemployed graduates should be extended in order to reduce their inactivity and the existing youth unemployment figures in Spain.

\section{Conclusions}

This descriptive and exploratory study, carried out in the context of COVID-19, shows the timeliness of this specialized university training. This descriptive and exploratory study shows that the university during the 2019/2020 academic year had a high rate of enrollment (1685 students). The increase in the number of students has been compared with other bachelor's and master's degree courses offered by the university. This shows the fluctuations in the number of enrollments, which is evidence of the interest levels of the students. The 1685 students enrolled in the MOOC are evidence of the interest in this 
training during the first impact of COVID-19 since, in past years, it did not reach this percentage of increase of 92.5 .

The main conclusion is that the three objectives set out in this study have been achieved. This confirmation is not sufficient to predict and advance the design of postgraduate and continuing education to fit a liquid labor market [61], since training is adapted to the socioeconomic circumstances and the needs of students, in times of pandemic especially [56]. Moreover, in this case, the unprecedented socio-health context that university institutions, including teaching staff and students, have had to face cannot be ignored.

Universities must respond to the real needs of university graduates, and not so much to the institutional needs of the university departments and their academic members, who generally live far removed from the demands and changes in the world of work, often due to the legal imperatives that affect them.

It is necessary to emphasize the high degree of student satisfaction with the training received [44], highlighting the training opportunities provided by MOOCs in this historical moment we are living in as a result of COVID-19. In our case, the students of the MOOC on "Social Health and Social Services in Social Work" have positively assessed the quality of the training received at this time and have considered the need to continue training in this specialty.

Therefore, at the turning point in the way in which online training is conceived, two key factors are taken into account: (a) the requirements of the labor market, and (b) the social and health contexts. MOOCs, and specifically the course analyzed in this study, show the potential of this learning modality, which should not be seen as a temporary methodology but, rather, as a new learning paradigm, as has recently occurred with teleworking in most of the world as a result of COVID-19 [62-65].

The pandemic has highlighted the usefulness of MOOCs which, through their platforms, make it possible to supplement the training that students receive in the classroom.

\section{Limitations}

The answers on the evaluation of the training received by the trainees show the usefulness of the contents acquired and the satisfaction with the course during the pandemic crisis. The results cannot be generalized.

Author Contributions: Conceptualization, methodology, validation, formal analysis, investigation, supervision, project administration: F.G.G. \& P.M.G. Both authors have read and agreed to the published version of the manuscript.

Funding: This research received no external funding.

Institutional Review Board Statement: Not applicable.

Informed Consent Statement: Not applicable.

Data Availability Statement: The results sent in this manuscript correspond to a research process carried out in accordance with the recommendations of the Ethics Committees of the National University of Distance Education (Madrid, Spain). The recommendations of these committees comply with the Declaration of Helsinki (seventh revision in 2013, Fortaleza, Brazil). All participants, of legal age, voluntarily agreed to participate in the research after receiving information about its purpose. The data generated in this study are available upon request.

Acknowledgments: Thank you to all the people who have made this study possible.

Conflicts of Interest: The authors declare no conflict of interest.

\section{References}

1. The UNED Revalidates Its Place in the National and International University World. Available online: http:/ / portal.uned.es/ portal/page?_pageid=93,70672720\&_dad=portal\&_schema=PORTAL (accessed on 3 July 2020).

2. Portal Estadístico Oficina de Tratamiento de la Información. Available online: https:/ / app.uned.es/evacal/genmat.aspx (accessed on 3 June 2021). 
3. Gobierno de España. Real Decreto 463/2020, de 14 de Marzo, por el que se Declara el Estado de Alarma Para la Gestión de la Situación de Crisis Sanitaria Ocasionada por el COVID-19; Publicado en el Boletín Oficial del Estado el 14/03/2020. Available online: https:/ / www.boe.es/buscar/doc.php?id=BOE-A-2020-3692.

4. Abuabara Franco, E.; Bohórquez Rivero, J.; Restom Arrieta, J.; Uparella Gulfo, I.; Restom Tinoco, J.; Sáenz López, J. Infección por SARS-COV-2 y enfermedad CO-VID-19: Revisión literaria. Rev. Científica Salud Uninorte 2020, 36, 196-230. [CrossRef]

5. Ministerio de Sanidad. Situación del COVID-19 en España; Ministerio de Sanidad: Madrid, Spain, 2021. Available online: https://www.mscbs.gob.es/profesionales/saludPublica/ccayes/alertasActual/nCov/situacionActual.htm (accessed on 31 July 2021).

6. Crisol-Moya, E.; Herrera-Nieves, L.; Montes-Soldado, R. Educación virtual para todos: Una revisión sistemática. Educ. Knowl. Soc. 2020, 21, 15. [CrossRef]

7. Sá, M.J.; Serpa, S. The COVID-19 Pandemic as an Opportunity to Foster the Sustaina-ble Development of Teaching in Higher Education. Sustainability 2020, 12, 8525. [CrossRef]

8. Acosta, T.; Luján-Mora, S. Accessibility of videos in MOOC during the COVID-19 pandemic: MOOCS CEC-EPN-Ecuador as an example. In Proceedings of the 13th International Conference on Education and New Learning Technologies, Edulearn 2021, Palma de Malloraca, Spain, 5-6 July 2021; pp. 5458-5467.

9. Acosta, T.; Zambrano-Miranda, J.; Luján-Mora, S. Techniques for the publication of accessible multimedia content on the web. IEEE Access 2020, 8, 55300-55322. [CrossRef]

10. Gómez-Galán, J.; Pérez-Parras, J. Luces y sombras del fenómeno MOOC: ¿representan una auténtica innovación educativa? Rev. Pedagog. 2017, 36, 237-259.

11. Gómez-Galán, J.; Martín, A.H.; Bernal, C.; López-Meneses, E. MOOC Courses and the Future of Higher Education:A New Pedagogical Framework; River Publishers: Aalborg, Denmark, 2019.

12. García-Peñalvo, F.J.; Fidalgo-Blanco, Á.; Sein-Echaluce, M.L. An adaptive hybrid MOOC model: Disrupting the MOOC concept in higher education. Telemat. Inform. 2018, 35, 1018-1030. [CrossRef]

13. Bournissen, J.M.; Tumino, M.C.; Carrión, F. MOOC: Evaluación y medición de la calidad percibida. Int. J. Educ. Res. Innov. 2019, $11,18-32$.

14. Fidalgo, A.; Sein, M.L.; García-Peñalvo, F.J. From massive access to cooperation: Lessons learned and proven results of a hybrid xMOOC/cMOOC pedagogical approach to MOOCs. Int. J. Educ. Technol. High. Educ. 2016, 13, 24. [CrossRef]

15. Bartolomé, A.R.; Steffens, K. ¿Son los MOOC una alternativa de aprendizaje? Comunicar 2015, 22, 91-99.

16. Dillahunt, T.; Wang, Z.; Teasley, S.D. Democratizing higher education: Exploring MOOC use among those who cannot afford a formal education. Int. Rev. Res. Open Distrib. Learn. 2014, 15, 177-196. [CrossRef]

17. McAuley, A.; Stewart, B.; Siemens, G.; Cormier, D. Massive Open Online Courses. Digital Ways of Knowing and Learning. In The MOOC Model for Digital Practice; University of Prince Edward Island: Charlottetown, PE, Canada, 2010.

18. Class Central. By the Numbers: MOOCs in 2015. Retrieved June 2016. Available online: https://www.class-central.com/report/ moocs-2015-stats/ (accessed on 7 July 2020).

19. Navarro Ortega, S.A.; Munuera Gómez, P. Accessibility and new technology MOOC- disability and active aging: Technological support. In Advances in Intelligent Systems and Computingthis Link Is Disabled; Springer Nature: New York, NY, USA, 2019; Volume 880, pp. 992-1004.

20. Ministrio de Universidades- Madrid, Spain. Available online: https://www.universidades.gob.es/portal/site/universidades/ menuitem.78fe777017742d34e0acc331002604a0/?vgnextoid=bdee7971195a7710VgnVCM1000001d04140aRCRD (accessed on 8 July 2021).

21. Oeawards for Excelence 2020. Available online: https://www.facebook.com/UNED.ES/photos/a.178673329744/1016046746413 4745 / (accessed on 20 October 2020).

22. Youtube: \#oeawards2020. Available online: https://www.youtube.com/hashtag/oeawards2020 (accessed on 8 July 2021).

23. Banihashem, K.; Farokhi, S.; Shahalizadeh, M.; Mashhadi, M. The effect of e-learning on students' creativity. Interdiscip. J. Virtual Learn. Med Sci. 2020, 5, 53-61.

24. Angarita, L.M.; Chiappe, A. Are ICT good partners for the development of creativity? A systematic review of literature. Int. J. Arts Technol. 2019, 11, 231-248. [CrossRef]

25. Bryndin, E. Creative innovative higher education of researchers with flexible skills and synergy of cooperation. Contemp. Res. Educ. Engl. Lang. Teach. 2019, 1, 1-6. [CrossRef]

26. Johnson, L.; Adams Becker, S.; Cummins, M.; Estrada, V.; Freeman, A.; Ludgate, H. NMC Horizon Report: 2013 Higher Education Edition; The New Media Consortium: Austin, TX, USA, 2013.

27. Pérez-Parras, J.; Gómez-Galán, J. Conocimiento y empleo de los cursos MOOC en estudiantes de Magisterio españoles: Implicaciones en su formación. In Investigaciones Educativas Hispano-Mexicanas; López-Meneses, E., Maldonado, G.A., Marín, V., Vázquez-Cano, E., Eds.; AFOE: Seville, Spain, 2017; pp. 190-208.

28. Yilmaz, Y.; Sarikaya, O.; Senol, Y.; Baykan, Z.; Karaca, O.; Nilufer DAltintas, L.; Onan, A.; Sayek, İ. RE-AIMing COVID-19 online learning for medical students: A massive open online course evaluation. BMC Med. Educ. 2021, 21, 303. [CrossRef] [PubMed]

29. Gütl, C.; Rizzardini, R.H.; Chang, V.; Morales, M. Attrition in MOOC: Lessons learned from drop-out Students. In Learn Technol Educ Cloud MOOC Big Data; Uden, L., Sinclair, J., Tao, Y.-H., Liberona, D., Eds.; Springer International Publishing: Cham, Switzerland, 2014; pp. 37-48. 
30. Nawrot, I.; Doucet, A. Building engagement for MOOC students: Introducing support for time management on online learning platforms. In Proceedings of the 23rd International Conference on World Wide Web, Seoul, Korea, 7-11 April 2014; Association for Computing Machinery: New York, NY, USA, 2014; pp. 1077-1082. [CrossRef]

31. Mairal Usón, R. Plan Estratégico UNED 2019-2022; UNED: Madrid, Spain, 2019.

32. Gobierno de España. Decreto 2310/1972, de 18 de agosto, por el que se crea la Universidad Nacional de Educación a Distancia. (BOE, 9/09/1972). BOE. Ley 31/1995, de 8 de Noviembre, de Prevención de Riesgos Laborales. Available online: https: / / url2.cl/tjRfD (accessed on 5 July 2020).

33. Cabero-Almenara, J.; Llorente-Cejudo, C. Covid-19: Radical transformation of digi-tization in university institutions. Campus Virtuales 2020, 9, 25-34.

34. Beltrán Hernández de Galindo, M.J.; Ramírez-Montoya, M.S. Innovation in the instructional design of open Mass Courses (MOOCs) to develop entrepreneurship compe-tencies in energy sustainability. Educ. Knowl. Soc. 2019, $20,5$.

35. Del Arco, I.; Flores, Ò.; Ramos-Pla, A. Modelo estructural para determinar los factores que inciden en la calidad de la enseñanza de emergencia, según la percepción del alumno de los primeros cursos universitarios. Sostenibilidad 2020, 13, 2945. [CrossRef]

36. del Arco, I.; Silva, P.; Flores, O. La docencia universitaria en tiempos de encierro: Luces y sombras del aprendizaje obligatorio en línea. Sostenibilidad 2021, 13, 375. [CrossRef]

37. Jacquet, G.; Umoren, R.; Hayward, A.; Myers, J.; Modi, P.; Dunlop, S.; Sarfaty, S.; Hauswald, M.; Tupesis, J.P. The Practitioner's Guide to Global Health: An interactive, online, open-access curriculum preparing medical learners for global health experiences. Med. Educ. Online 2018, 23, 1503914. [CrossRef]

38. Martínez-López, J.Á.; Lázaro-Pérez, C.; Gómez-Galán, J. Burnout among Direct-Care Workers in Nursing Homes during the COVID-19 Pandemic in Spain: A Preventive and Educational Focus for Sustainable Workplaces. Sustainability 2021, $13,2782$. [CrossRef]

39. Martínez-López, J.Á.; Lázaro-Pérez, C.; Gómez-Galán, J. Death Anxiety in Social Workers as a Consequence of the COVID-19 Pandemic. Behav. Sci. 2021, 11, 61. [CrossRef] [PubMed]

40. Cordero del Castillo, P. El COVID-19, desafía a la sociedad. Humanismo Trab. Soc. 2020, 19, 55-63.

41. Lázaro-Pérez, C.; Martínez-López, J.Á.; Gómez-Galán, J.; López-Meneses, E. Anxiety about the risk of death of their patients in health professionals in spain: Analysis at the peak of the COVID-19 pandemic. Int. J. Environ. Res. Public Health 2020, 17, 5938. [CrossRef] [PubMed]

42. COTSM Colegio Oficial de Trabajadores Sociales de Madrid. Trabajo Social y Sistema Público de Salud. 2007. Available online: www.comtrabajosocial.com/documentos.asp?id=832 (accessed on 24 July 2021).

43. Ramos-Pla, A.; Selva Pareja, L. (Eds.) DOTS Educa, 10 Meses 10 Retos; Editorial Dykinson: Madrid, Spain, 2020; ISBN 978-84-1377-168-7.

44. Khan, M.A.; Vivek; Nabi, M.K.; Khojah, M.; Tahir, M. Students' Perception towards E-Learning during COVID-19 Pandemic in India: An Empirical Study. Sustainability 2021, 13, 57. [CrossRef]

45. Munuera Gómez, P.; Gómez Gómez, F. Docencia E-Learning y Moocs. Innovación en la Formación en dos Universidades. Available online: https://www.researchgate.net/publication/344751416_DOCENCIA_E-LEARNING_Y_MOOCS_INNOVACION_ EN_LA_FORMACION_EN_DOS_UNIVERSIDADES (accessed on 30 October 2018).

46. Moreira, M.A.; Aguilar, A.B.; Gómez, S.M. De la enseñanza se-mipresencial a la enseñanza online en tiempos de Covid19. Visiones del alumnado. Campus Virtuales 2020, 9, 35-50.

47. Valverde-Berrocoso, J.; Garrido-Arroyo, M.D.C.; Burgos-Videla, C.; Morales-Cevallos, M. Trends in educational research about e-learning: A systematic literature review (2009-2018). Sustainability 2020, 12, 5153. [CrossRef]

48. Alturkistani, A.; Majeed, A.; Car, J.; Brindley, D.; Wells, G.; Meinert, E. Data colle-tion approaches to enable evaluation of a massive open online course about data science for continuing education in health care: Case study. JMIR Med. Educ. 2019, 5, e10982. [CrossRef]

49. Zhu, M.; Sari, A.; Lee, M.M. A systematic review of research methods and topics of the empirical MOOC literature (2014-2016). Internet High Educ. 2018, 37, 31-39. [CrossRef]

50. Chapman, S.A.; Goodman, S.; Jawitz, J.; Deacon, A. A strategy for monitoring and evaluating massive open online courses. Eval Program Plann. 2016, 57, 55-63. [CrossRef]

51. Tahiri, J.; Bennani, S.; Idrissi, M. Using an analytical formalism to diagnostic and evaluate Massive Open Online Courses. In Proceedings of the 2015 10th International Conference on Intelligent Systems: Theories and Applications (SITA), Rabat, Morocco, 20-21 October 2015; p. 1.

52. Gómez Gómez, F. Competencias profesionales en Trabajo Social. Portularia 2010, 10, 51-63. [CrossRef]

53. Gómez Gómez, F.; Herrador Buendía, F. Tareas y acciones de los trabajadores sociales. Un estudio comparativo entre España y Ecuador. Doc. Trab. Soc. Rev. Trab. Soc. Acción Soc. 2008, 43-44, 137-154.

54. Gil Martorell, D. Es mucho más importante saber qué clase de paciente tiene una enfermedad, qué saber qué clase de enfermedad tiene un paciente. Trab. Soc. Salud 2012, 72, 75-82.

55. Munuera, P. El trabajo social sanitario en situaciones de pandemia y coronavirus. En Jimenez, J.M. y Munuera, P. In Fundamentos del Trabajo Social Sanitario. Análisis de su Recorrido Histórico Hasta la Actual Pandemia; Tirant lo Blanch: Valecia, Spain, 2020.

56. Gómez Gómez, F.; Munuera Gómez, P. Experiencias grupales innovadoras en la Segunda Especialidad en Orientación y Consejería al Niño, Adolescente y Psicoterapia Familiar. In Encuentro Sobre Experiencias Grupales Innovadoras en la Docencia Universitaria; Universidad Complutense de Madrid: Madrid, Spain, 2007; pp. 1-7. 
57. García-Peñalvo, F.J. Transformación digital en las universidades: Implicaciones de la pandemia de la COVID-19. Educ. Knowl. Soc. 2021, 22, e25465. [CrossRef]

58. Cervi, L.; Pérez Tornero, J.M.; Tejedor, S. The challenge of teaching mobile journalism through MOOCs: A case study. Sustainability 2020, 12, 5307. [CrossRef]

59. Munuera, P.; (coord.). El Impacto de las Nuevas Tecnologías (TIC) en Discapacidad y Envejecimiento Activo; Tirant lo Blanch: Valencia, Spain, 2016

60. Gómez-Galán, J.; Lázaro-Pérez, C.; Martínez-López, J. Exploratory Study on Video Game Addiction of College Students in a Pandemic Scenario. J. New Approaches Educ. Res. 2021, 10, 330-346. [CrossRef]

61. Bauman, Z. Tiempos Líquidos: Vivir en una Época de Incertidumbre; Tusquets Editores: Barcelona, Spain, 2017.

62. Belzunegui-Eraso, A.; Erro-Garcés, A. Teleworking in the Context of the Covid-19 Crisis. Sustainability 2020, 12, 3662. [CrossRef]

63. Morilla-Luchena, A.; Muñoz-Moreno, R.; Chaves-Montero, A.; Vázquez-Aguado, O. Telework and Social Services in Spain during the COVID-19 Pandemic. Int. J. Environ. Res. Public Health 2021, 18, 725. [CrossRef] [PubMed]

64. Vargo, D.; Zhu, L.; Benwell, B.; Yan, Z. Digital technology use during COVID-19 pandemic: A rapid review. Hum. Behav. Emerg. Technol. 2021, 3, 13-24. [CrossRef]

65. Carillo, K.; Cachat-Rosset, G.; Marsan, J.; Saba, T.; Klarsfeld, A. Adjusting to epidemic-induced telework: Empirical insights from teleworkers in France. Eur. J. Inf. Syst. 2021, 30, 69-88. [CrossRef] 